Agro-Science Journal of Tropical Agriculture, Food, Environment and Extension Volume 8 Number 3 Sentember 2009 nn 145-150

ISSN 1119-7455

\title{
MULCHING AN ARENIC HAPLUDULT IN SOUTHEASTERN NIGERIA: EFFECTS ON SELECTED SOIL PROPERTIES AND RHIZOME YIELD OF TURMERIC.
}

\author{
Nwokocha $^{1}$, C. C., Mbagwu ${ }^{2}$, J. S. C., Olojede ${ }^{1}$, A. O. and Ano ${ }^{1}$, A. O. \\ ${ }^{1}$ National Root Crops Research Institute Umudike \\ P. M. B. 7006 Umuahia Abia State Nigeria. \\ ${ }^{2}$ Department of Soil Science University of Nigeria, Nsukka, Nigeria
}

\begin{abstract}
A study was carried out over two cropping seasons at Umudike, southeastern Nigeria, to determine the type and quantity of mulch that would improve some selected physical properties of an Arenic Hapludult and optimize the rhizome yield of turmeric. Effects of mulch rate on bulk density (BD), total porosity (TP), macro-porosity (Ma. P), water stable aggregates (WSA $>0.5 \mathrm{~mm}$ ) and mean-weight diameter (MWD) significantly depended on the type of mulch material used. Straw mulch reduced BD and increased other parameters more than wood shavings. Optimum values of WSA $>0.5 \mathrm{~mm}$ (23.2) and MWD (0.535) occurred at the $4 \mathrm{t} / \mathrm{ha}$ mulch rate, whereas, maximum values of TP (54.08\%), Ma. $P(26.55 \%)$ and minimum value of $B D\left(1.51 \mathrm{~g} / \mathrm{cm}^{3}\right)$, were achieved at mulching beyond 4 t/ha. Apart from total porosity, which was found to be optimum, BD, organic carbon (OC), Ma. $P$ and MWD explained individually between 80 and $99 \%$ of the variability in yield. Results also showed that all mulched plots out-yielded the bare plots. Rhizome yield varied with the rate of mulch application with yield increases declining in the order 8,4 and 0 t/ha mulch rate. Increase in the rhizome yield of turmeric was dependent on the type of mulch used, with straw mulch out-yielding wood shavings by 38.4 and $76.6 \%$ in 2004 and 2005 , respectively.
\end{abstract}

Keywords: Turmeric rhizomes, soil physical properties, mulching, arenic hapludult

\section{INTRODUCTION}

Turmeric is a shallow-rooted crop and an herbaceous plant with thick and fleshy rhizomes. It belongs to the genus Curcuma and to the family, Zingiberaceae, and consists of many species. Curcuma longa Linn is the highest yielding turmeric of commercial value. Its origin has been traced to South and Southeast Asia. India is reputed to be the largest producer of turmeric. Turmeric is used as a spice and is the main constituent of curry powder. Besides its use as a spice, turmeric finds a place in the cosmetics industry for its brilliant yellow colour and characteristic perfume. It is also being used as a dye for colouring fabrics among other uses.

A crop's genetic potential and environmental setting usually control its yield. However, soil conditions at the rooting depth of a crop influence the full exploitation of its genetic potentials. Any sound soil management programme must provide three conditions: a satisfactory state of soil tilth for the development of the root; an adequate amount of the right kind of plant nutrients for good crop production; and protection against excessive soil loss and run off.
Mulch practices have been shown to satisfy these conditions through their effects on soil and water conservation (Fournier 1967; Lal et al., 1980; Adeoye, 1982).

Crop residues have numerous competing uses such as fodder, fuel, construction and mulch materials. Similarly, costs are incurred in its application and these costs increase with mulch rate. Therefore, it is necessary to establish optimum mulch application rates. Mulumba and Lal (2008) studied the long term (11 years) effects of mulching $(0,2,4$, $8,16 \mathrm{t} / \mathrm{ha} /$ year without crop cultivation) on soil physical properties of a silt loam Arenic Ochraqualf in central Ohio. Results demonstrated that mulch rates significantly increased available water capacity by $18-35 \%$, total porosity by $35-46 \%$ and soil moisture retention at low suctions from $29-70 \%$. At high suctions, no differences in soil moisture content were observed between mulch levels. Soil bulk density was not affected by mulch rate. High correlations were obtained between mulch rate and soil mean weight diameter $\left(\mathrm{R}^{2}=0.87\right)$ and percent water-stable aggregates $\left(R^{2}=0.84\right)$. The study was 
able to determine optimum rate of $4 \mathrm{t} / \mathrm{ha}$ for increased porosity and $8 \mathrm{t} / \mathrm{ha}$ for enhanced available water capacity, moisture retention and aggregate stability.

Mbagwu (2006) determined the minimum rate of straw mulch for optimising the physical conditions of the top soil $(0-20 \mathrm{~cm}$ depth) of a fragile ultisol and maize (Zea mays) and cowpea (Vigna unguiculata L.Walp) yields. Results obtained showed that water retention and percent water- stable aggregates $>0.5$ $\mathrm{mm}$ were maximal, whereas soil compaction (measured by dry bulk density) was minimal at the $2.0 \mathrm{t} / \mathrm{ha}$ mulch rate. Maize and cowpea yields were optimal at the $4.0 \mathrm{t} / \mathrm{ha}$ rate with respective increases over the bare plots of 80 and $67 \%$ at that rate. However, according to Lentz and Bjorneberg (2003), residue mulching may not always improve soil physical properties because positive effects depend on the quality and quantity of residue applied, management duration, tillage system, site-specific soil properties, and climate. Lal (1995) had reported that the magnitude of mulch effects on nutrient supply and improvement on soil physical properties depended on the quantity and quality of mulch, soil properties and prevailing climatic conditions. The objectives of the research were to: (1) determine the type and quantity of mulch material that would optimize the physical properties of an Arenic Hapludult; and (2) evaluate their effects on the rhizome yield of turmeric.

\section{MATERIALS AND METHOD}

This study was carried out for two consecutive cropping seasons (2004 / 05 and 2005/06) in the National Root Crops Research Institute (NRCRI) Umudike Research Farm (latitude $05^{\circ} 29^{\prime} \mathrm{N}$; longitude $07^{\circ} 33^{\prime}$ E) in southeastern Nigeria on a loamy sand soil (Arenic Hapludult). The site was disc-ploughed and disc-harrowed to a depth of about $20 \mathrm{~cm}$. Beds, each measuring, $3 \mathrm{~m} \times 2 \mathrm{~m}$, were made with a one metre distance separating adjacent beds. The experimental design used was split plot in randomized complete block design (RCBD) with three replications. The main plot treatments were two mulch types, straw (Pennisentum purpereum) and wood shavings. The sub- plot treatments comprised three mulch rates $(0,4$, and $8 \mathrm{t} / \mathrm{ha})$. Planting was done in June each year. The mulch treatments (dry weights) were applied immediately after planting. Fertilizer (N. P. K, 15:15:15) was applied 8 weeks after planting (WAP) at the rate of $400 \mathrm{~kg} / \mathrm{ha}$. Primextra and gramazone herbicides were applied, as pre-emergence, at the rates of 1.5 and $0.53 \mathrm{~kg} / \mathrm{ha}$ active ingredients, respectively. Supportive rouging was done at regular intervals to keep the plots weed free. The crop was harvested in January (28 WAP) and the rhizome yield ( $\mathrm{t} / \mathrm{ha}$ ) measured. Yield from the mulched plots were compared with the yield from unmulched (control) plots by computing a mulch factor thus:

$$
\mathrm{M}=((\mathrm{Ym} / \mathrm{Yc}) 1) \times 100 \ldots \ldots \ldots \ldots(1)
$$

where $\mathrm{M}=$ mulch factor (i.e. the percentage increase in yield over the control due to mulching); $\mathrm{Ym}=$ yield on the mulched plot and $\mathrm{Yc}=$ yield on the control plot.

Bulk density was calculated by the method of Blake and Hartge (1986a). Total porosity (TP), was determined using the relationship between soil bulk density (BD) and particle density (PD) (Blake and Hartge, 1986b). Macro-porosity (Ma. P) and microporosity (Mi. P) were calculated from bulk density values, with assumed particle density of $2.65 \mathrm{Mg} \mathrm{m}^{-3}$, as follows:

$\mathrm{TP}=100(1-\mathrm{BD} / \mathrm{PD})$;

Ma. $\mathrm{P}=\mathrm{TP}-\theta$ (60 cm tension); and Mi. P = TP - Ma. $\mathrm{P}$; where $\theta$ is the volumetric water content.

Water stable aggregate (WSA $>0.5 \mathrm{~mm}$ ) was determined following the methods of Kemper and Rosenau (1986). Mean-weight diameter (MWD) was calculated from water stable aggregates using the formular:

MWD $=\sum_{\mathrm{i}=1}^{\mathrm{n}} \mathrm{Xi} \mathrm{Wi}$

where $\mathrm{Xi}$ is the diameter of the ith sieve size and $\mathrm{Wi}$ is the proportion of the total aggregates in the ith fraction, and $\mathrm{n}=$ total number of size fractions (Kemper and Rosenau, 1986). Particle size distribution was measured by the hydrometer method as described by Gee and Bauder (1986). Percent organic carbon (\%O.C.) was determined by the dichromate oxidation method of Walkley and Black method (Nelson and Sommers, 1982). Total nitrogen was determined by micro-Kjeldahl method (Bremner and Mulvaney, 1982). Soil $\mathrm{pH}\left(\mathrm{H}_{2} \mathrm{O}\right)$ was measured (soil / water ratio of $1: 2.5$ ) with a digital $\mathrm{pH}$ meter (McLean, 1982). Exchangeable bases were extracted with $1 \mathrm{~N} \mathrm{NH}_{4} \mathrm{OAc}$ (Jackson, 1958). Exchangeable acidity was determined by the titrimetric method after extraction with 1.0 M KCl (McLean, 1982). Effective cation exchange capacity (ECEC) was determined from the sum of the exchangeable bases and the exchangeable acidity. Statistical method of analysis of variance for a split plot design as outlined by Steel and Torrie (1980) was used for the analysis. Mean separation for significant $(\mathrm{P}<0.05)$ effects was carried out using F-LSD, as described by Obi (1986). Correlation coefficients, coefficients of determination and regression equations, were used to explain relationships between yield and soil properties. 


\section{RESULTS AND DISCUSSION EXPERIMENTAL SITE}

The selected soil physical properties of the study site before treatment application are as shown in Table 1 . The soil was loamy sand, with acidic soil reaction. Total N, exchangeable K, ECEC, and OC, were very low. The low nutrient status of the soil is desirable, for easy detection of treatment responses. The rainfall distribution as recorded at Umudike, followed the bimodal pattern, typical of the tropical rainforest. The first and second peaks were in July and September respectively in both years (Table 2). Total annual rainfall amount, within the period of study ranged from 1911.4 to $2054.8 \mathrm{~mm}$. Turmeric is known for its wide range of ecological adaptation with regard to poor soil and harsh climatic conditions.

\section{Chemical characteristics of the mulch materials used.}

Chemical characteristics of the mulch materials used are shown in Table 3. The organic matter content was high $(5.10 \%)$ in straw, but low $(1.31 \%)$ in wood shavings. Total $\mathrm{N}$ was low $(0.126 \%)$, in straw, but high $(0.378 \%)$, in wood shavings. Available $\mathrm{K}$ was high in both straw $(0.50 \mathrm{mg} / \mathrm{kg})$, and wood shavings $(0.640 \mathrm{mg} / \mathrm{kg})$. Straw had wider $\mathrm{C} / \mathrm{N}$ ratio $(23.5: 1)$, than wood shavings $(2: 1)$. Mulch material with wide $\mathrm{C} / \mathrm{N}$ ratio would serve as better mulch, as decomposition will take a longer time to be achieved.

Table 1. Physico-chemical properties of soil of the study site at the start of the experiment

\begin{tabular}{lr}
\hline Property & Values \\
\hline Sand (\%) & 81.8 \\
Silt (\%) & 7.4 \\
Clay (\%) & 10.8 \\
Texture & $\mathrm{LS}$ \\
Organic Carbon (\%) $\left._{\text {pH(H }} \mathrm{O}\right)$ & 0.75 \\
ECEC cmolkg & 5.42 \\
Total Nitrogen $(\%)$ & 3.98 \\
Available K (ppm) & 0.084 \\
Carbon/Nitrogen $(\mathrm{C} / \mathrm{N})$ & 0.102 \\
\hline
\end{tabular}

a. $\mathrm{LS}=$ loamy sand; $\mathrm{b}$. ECEC = effective cation exchange capacity

Table 2. Rainfall data of the experimental site for 2004 and 2005

\begin{tabular}{lcccc}
\hline & \multicolumn{4}{c}{ Year } \\
\cline { 2 - 5 } & \multicolumn{2}{c}{$\mathbf{2 0 0 4}$} & & $\mathbf{2 0 0 5}$ \\
\cline { 2 - 5 } Month & $\begin{array}{l}\text { Rainfall } \\
\text { amount (mm) }\end{array}$ & $\begin{array}{l}\text { Number of } \\
\text { rainy days }\end{array}$ & $\begin{array}{l}\text { Rainfall } \\
\text { amount (mm) }\end{array}$ & $\begin{array}{c}\text { Number of } \\
\text { rainy days }\end{array}$ \\
\hline January & 0.2 & 0 & 17.3 & 2 \\
February & 11.9 & 2 & 126.7 & 5 \\
March & 22.4 & 4 & 64.0 & 6 \\
April & 134.5 & 9 & 141.3 & 11 \\
May & 217.6 & 11 & 222.4 & 17 \\
June & 279.4 & 18 & 264.4 & 18 \\
July & 309.5 & 18 & 277.0 & 24 \\
August & 304.3 & 21 & 225.0 & 21 \\
September & 324.9 & 19 & 339.7 & 17 \\
October & 249.1 & 16 & 323.0 & 6 \\
November & 5.5 & 4 & 45.4 & 2 \\
December & 5.1 & 1 & 8.6 & $\mathbf{1 4 7}$ \\
Total & $\mathbf{1 9 1 1 . 4}$ & $\mathbf{1 2 3}$ & $\mathbf{2 0 5 4 . 8}$ & \\
\hline
\end{tabular}

Source: National Root Crops Research Institute Meteorology Station, Umudike 
Effects of mulching on selected soil properties and rhizome yield of turmeric.

Table 3.Chemical characteristics of the mulch materials used

\begin{tabular}{lcc}
\hline & \multicolumn{2}{c}{ Mulch Type } \\
\cline { 2 - 3 } Property & Straw & Wood shavings \\
\hline Organic carbon $(\%)$ & 2.96 & 0.76 \\
Total nitrogen $(\%)$ & 0.126 & 0.378 \\
Available Potassium $(\mathrm{mg} / \mathrm{kg})$ & 0.50 & 0.640 \\
C/N ratio & $23.5: 1$ & $2: 1$ \\
\hline
\end{tabular}

Effects of mulch application on BD, MWD, TP, WSA > $0.5 \mathrm{~mm}$ and Ma. P.

Mulch rate significantly affected $\mathrm{BD}, \mathrm{Pt}, \mathrm{Pe}$ and MWD. However, mulch type significantly influenced only Pe and MWD (Table 4). Increase in mulch rate increased MWD, WSA > $0.5 \mathrm{~mm}$, Ma. P and TP, but reduced $\mathrm{BD}$. Maximum values for $\mathrm{Ma}$. $\mathrm{P}(26.55 \%)$ and TP $(54.08 \%)$ were obtained at $8 \mathrm{t} / \mathrm{ha}$ rate, whereas for macro aggregate stability indices (WSA $>0.5 \mathrm{~mm}$ and MWD), optimum values were obtained at the $4 \mathrm{t} / \mathrm{ha}$ mulch rate. Lower $\mathrm{BD}$ and higher TP, Ma. P and WSA > $0.5 \mathrm{~mm}$ was observed in mulched plots and as mulch rate increased. This may have resulted from the beneficial effects of a mulch cover to breakdown the kinetic energy of the rain drops, thereby reducing their impact on the soil, resulting in reduced soil compaction and aggregate disintegration. It would appear that the decomposition of the mulch materials provided soil organic matter (SOM) which helped to stabilize the aggregate, explaining the lower values of $\mathrm{BD}$ and higher values of WSA $>0.5 \mathrm{~mm}$, TP and Ma. P obtained on mulched plots.

\section{Effect of treatments on rhizome yield of turmeric.}

The effects of mulch type and rate on rhizome yield of turmeric in 2004 and 2005 are presented in Table 5. Mulch type and rate showed highly significant effects $(\mathrm{P}=0.001)$ on yield. Mulching with straw compared to wood shavings resulted in much higher rhizome yield. Total rhizome yield per hectare increased by $38.62 \%$ in 2004 and by $76.64 \%$ in 2005. Straw contains higher percent OM, conserves soil moisture better, and improves soil structure better than wood shavings (Nwokocha et al., 2006).

Table 5. Rhizome yield of turmeric as influenced by mulch application at Umudike.

\begin{tabular}{lccc}
\hline & \multicolumn{2}{c}{ Rhizome yield (t/ha) } & \\
\cline { 2 - 3 } Treatments & 2004 & 2005 & Means \\
\hline Mulch type & & & \\
Straw & 10.23 & 10.51 & 10.37 \\
Wood shavings & 7.38 & 5.95 & 6.67 \\
LSD $(0.05)$ & $0.75^{* *}$ & $0.25^{* *}$ & \\
Mulch rate (t/ha) & & & \\
0 & 4.06 & 3.52 & 3.79 \\
4 & 10.60 & 8.66 & 9.63 \\
8 & 11.76 & 12.51 & 12.14 \\
LSD $(0.05)$ & $1.05^{* *}$ & $0.48^{* *}$ & \\
\hline
\end{tabular}

$* * *=$ Significant at $5 \%$ and $1 \%$ alpha levels; NS = Not significant at $5 \%$ alpha level
These attributes of straw over wood shavings might have been responsible for the higher rhizome yield observed in straw-mulched plots. Mulch rate significantly influenced $(\mathrm{P}=0.01)$ rhizome yield in both years (Table 5). The increase in yield due to mulch rate followed the trend; $8>4>0$ t/ha in both cropping seasons. This confirms the observation of Lal (1975), that the ability of mulch to enhance soil quality and improve yield, depends on the quantity and quality of mulch applied.

The computed mulch factor value was higher in $2005(255 \%)$ than in $2004(189 \%)$, at the $8 \mathrm{t} / \mathrm{ha}$ mulch rate (Fig. 1). In 2004 (first year of study), a mulch factor improvement of $29 \%$ was achieved whereas, in 2005 (second year of study), a higher mulch factor improvement of $109 \%$ was recorded.

Yield of Turmeric and Soil Physical Properties

Apart from total porosity, other soil properties explained individually between 80 and $99 \%$ variability in yield (Table 6). Non significant relationship between turmeric yield and total porosity implied that total porosity was optimal for turmeric performance. Negative correlation between bulk density and turmeric yield, like in other root crops, was expected. By reducing bulk density, mulching helped to improve root penetration.

\begin{tabular}{lccccc}
\multicolumn{5}{l}{ Table 4. Effects of mulch type and rate on some selected physical properties of an Ultisol at Umudike. } \\
\hline Treatments & $\begin{array}{c}\text { TP } \\
(\%)\end{array}$ & $\begin{array}{l}\text { Ma.P } \\
(\%)\end{array}$ & $\begin{array}{c}\text { BD } \\
\left(\mathbf{g} / \mathrm{cm}^{3}\right)\end{array}$ & $\begin{array}{c}\text { MWD } \\
(\%)\end{array}$ & $\begin{array}{c}\text { WSA } \\
(\%)\end{array}$ \\
\hline Mulchtype & 50.13 & 21.33 & 1.56 & 0.528 & 21.52 \\
Straw & 51.91 & 18.92 & 1.55 & 0.508 & 18.79 \\
Wood shavings & $\mathrm{NS}$ & $0.21^{* *}$ & $\mathrm{NS}$ & $0.015^{*}$ & NS \\
LSD (0.05) & & & & & \\
Mulch rate (t/ha) & 49.71 & 11.55 & 1.57 & 0.466 & 13.71 \\
0 & 49.29 & 22.26 & 1.58 & 0.535 & 23.15 \\
4 & 54.08 & 26.55 & 1.51 & 0.555 & 23.60 \\
8 & $2.08^{* *}$ & $0.64^{* *}$ & $0.03^{*}$ & $0.040^{*}$ & $3.11^{* *}$ \\
\hline LSD $(0.05)$ & & & & &
\end{tabular}

$*, * *=$ Significant at 5 and $1 \%$ alpha levels respectively; NS = Not significant at $5 \%$ probability level.

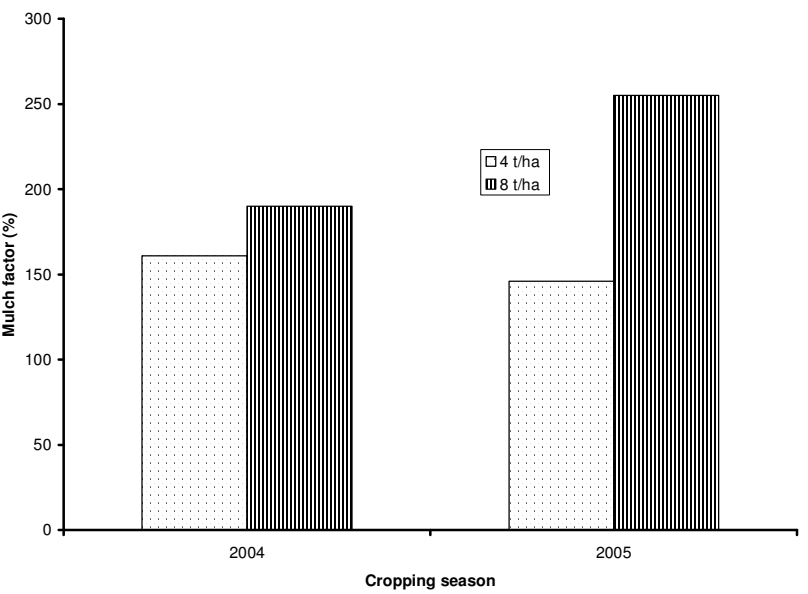

Fig. 1. Influence of mulch rate on rhizome yield of turmeric in an Ultisol 
Table 6. Relationships between turmeric rhizomes yield and some physical properties of an Ultisol ( $\mathrm{Y}$ in $\mathrm{t} / \mathrm{ha}$ )

\begin{tabular}{lcc}
\hline Dependent variables $(\mathbf{N}=\mathbf{1 8})$ & Regression models & $\mathbf{R}^{2}$ \\
\hline Water stable aggregates $(\mathrm{WSA}>0.5 \mathrm{~mm})$ & $\mathrm{Y}=0.61+0.41(\mathrm{WSA}>0.5 \mathrm{~mm})$ & $0.90^{* *}$ \\
Bulk density $(\mathrm{BD})$ & $\mathrm{Y}=55.330 .71(\mathrm{BD})$ & $0.99^{*}$ \\
Organic matter $(\mathrm{OM})$ & $\mathrm{Y}=2.19+8.80(\mathrm{OM})$ & $0.80^{* *}$ \\
Total porosity $\left(\mathrm{P}_{\mathrm{t}}\right)$ & $\mathrm{Y}=3.06+0.11(\mathrm{P})$ & $\mathrm{NS}$ \\
Macro-porosity $\left(\mathrm{P}_{\mathrm{e}}\right)$ & $\mathrm{Y}=-2.60+0.53(\mathrm{P})$ & $0.89^{* *}$ \\
Mean weight diameter $(\mathrm{MWD})$ & $\mathrm{Y}=-7.77+31.97(\mathrm{MWD})$ & $0.98^{* *}$ \\
\hline
\end{tabular}

$*, * *=$ Significant at 5 and $1 \%$ alpha levels respectively; NS = Not significant at 5\% alpha level.

\section{CONCLUSIONS}

The results of this study showed that all mulched plots out-yielded the bare plots. Yields varied with the rate of mulch application, with yield increases declining in the order 8,4 and 0 $\mathrm{t} / \mathrm{ha}$ mulch rate. Increase in the rhizome yield of turmeric was dependent on the mulch type used with straw mulch out-yielding wood shavings. Effects of mulch rate on BD, TP , Ma. P, WSA > $0.5 \mathrm{~mm}$ and MWD were dependent on the type of mulch material used. Straw mulch reduced BD and increased TP, Ma. P, WSA $>0.5 \mathrm{~mm}$ and MWD more than wood shavings. Optimum values of MWD and WSA $>0.5 \mathrm{~mm}$ for soil improvement occurred at the $4 \mathrm{t} / \mathrm{ha}$ mulch rate, whereas, for TP , Ma. P and BD, optimum rate was achieved at mulching beyond $4 \mathrm{t} / \mathrm{ha}$. Decreases in WSA $>0.5 \mathrm{~mm}$, Ma. P , and MWD on the bare plots were detrimental to the rhizome development of turmeric. Apart from total porosity, which was found to be optimum, BD, OC, Ma. P and MWD explained individually between 80 and $99 \%$ variability in yield. Negative correlation observed between BD and rhizome yield of turmeric, was as expected in all root crops.

\section{REFERENCES}

Adeoye, K. B. (1982). Effect of tillage depth on pnd cotton. Soil and Tillage Res. 2: 115231.

Blake, G. R. and Hartge, K. H. (1986a). Bulk density. In: A. Klute (Ed.) Methods of Soil Analysis, Part I, Agronomy 2nd ed. No 9., ASA., Madison, WI pp. 363-382.

Blake, G. R. and Hartge, K. H. (1986b). Particle density. In: A. Klute(Ed.) Methods of Soil Analysis, Part I, Agronomy 2nd ed. No 9., ASA., Madison, WI pp. 377-375.

Bremner, J. M. and Mulvancy, C. S. (1982). Total nitrogen. In: A. L. Page (Ed.) Methods of oil Analysis, Part II, Agronomy 2nd ed. No 9., ASA., Madison, WI pp. 595-624.
Fournier, F. (1967). Research on soil erosion and soil conservation in Africa. African Soils 12: 5396.

Gee, G. W. and Bauder, J. W. (1986). Particlesize analysis. In: Klute. A. (Ed.) Methods of Soil Analysis, Part I, Agronomy 2nd ed. No 9., ASA., Madison, WI pp. 91-100.

Jackson, M. C. (1958). Soil Chemical Analysis. Prentice Hall Eaglewood Cliffs. New Jersey. $498 \mathrm{pp}$.

Kemper, W. D., and Rosenau, R. C. (1986). Aggregate stability and size distribution of aggregates. In: A. Klute (Ed.) Methods of Soil Analysis, Part I, Agronomy 2nd ed. No 9., ASA., Madison, WI pp. 425442.

Lal, R. (1975). Role of Mulching Techniques in Tropical Soil and Water Management. Technical Bulletin No 1. International Institute of Tropical Agriculture Ibadan.38 pp.

Lal, R., De Vleecauwer, D., and Malafa Nganje, R. (1980). Changes in properties of a newly cleared tropical Alfisols as affected by mulching. Soil Sci. Soc. Am. J. 1980; 44: 827 833.

Lal, R. (1995). The Role of Residues Management in Sustainable Agricultural Systems. Journal of Sustainable Agriculture, 5 (4) 1995. The Haworth Press Inc.

Lal, R. (2000). Mulching effects on soil physical quality of an Alfisols in Western Nigeria. Land Degradation and Develop. II. John Wiley and Sons Ltd pp. 383392

Lentz, R. D. And Bjorneberg, D. L. (2003). Polyacrylamide and straw residue effects on irrigation furrow erosion and infiltration. $\mathrm{J}$. Soil Water Conserv. 58:312 - 319.

Mbagwu, Joe. S. C. (2006). Mulching an ultisol in southern Nigeria: Effects on physical properties and maize and cowpea yields. 
Journal of the Science of Food and Science. Vol. 57. Issue 4, p 517 - 526.

Mclean, E. O. (1982). Soil pH and lime requirements. In: A.L. Page (Ed.) Methods of Soil Analysis, Part II, Agronomy 2nd ed. No 9., ASA., Madison, WI pp. 199 - 224.

Mulumba, L. N. And Lal, R. (2008). Mulching effects on selected soil physical properties. Soil and Tillage Research Vol. 98. Issue 1, p. 106 - 111.

Nelson, D. W. and Sommers, L. E. (1982). Total carbon, organic carbon and organic matter. In: A.L. Page (Ed.) Methods of Soil Analysis, Part II, Agronomy 2nd ed. No 9., ASA., Madison, WI pp.539-579.

Nwokocha, C. C., Olojede, A. O., Ano, A. O. and Mbagwu, J. S. C. (2006). Mulching an Ultisol At Umudike: effects on aggregate stability and rhizome yield of turmeric (Curcuma longa Linn). In: G. N. Asumugha, A. O. Olojede, J. G. Ikeorgu, A. O. Ano and U. Herbert (Eds). Repositioning agriculture for sustainable millennium development goals in Nigeria. Proceedings of the 40th Annual Conference of the Agricultural Society of Nigeria (ASN). Held at N.R.C.R.I. Umudike, Abia State, Nigeria, October 16 20, 2006. pp. 378381 .
Obi, I. U. (1986). Statistical Methods of Detecting Differences between Treatment Means. SNNAP Press Enugu. Nigeria pp. 1 - 45.

Steel, R. G. and Torrie, J. H. (1980). Principles and Procedures of Statistics: A Biometrical Approach. 2nd edition. McGraw-Hill Co. Inc. New York. 